\section{AZ ÜGYFELEK VÉDELME AZ EGYSÉGES EURÓPAI PIACOKON EGYSÉGES SZABÁLYOZÁST IS IGÉNYEL GILYÉN ÁGNES BESZÉLGETÉSE Dr. FARKAS ÁDÁMMAL}

Gilyén Ágnes (Magyar Biztositók Szövetsége) agnes.gilyen@mabisz.hu

\section{ÖSSZEFOGLALÓ}

Farkas Ádám jelenleg az Európai Bankhatóság főigazgatója, ezt a pozíciót az EBA 2011-es megalakulása óta tölti be. Ezt megelőzően, 2009 és 2010 között a Pénzügyi Szervezetek Állami Felügyeletének elnöke volt. A felügyeleti és szabályozói területhez történő csatlakozását megelőzően a bankszektorban töltött be felsővezetői pozíciókat, többek között 3 éven át volt az Intesa bankcsoport magyarországi leányvállalatának, a CIB Banknak társvezérigazgatója Budapesten, valamint három éven át vezette az Allianz Bankot, mely időszak alatt felépítette a vezető biztosító magyarországi lakossági banki üzletágát. Korábban négy éven át a Magyar Nemzeti Bank piaci műveletekért és tartalékmenedzsmentért felelős ügyvezető igazgatója és igazgatósági tagja. Szakmai pályafutását a Budapesti Corvinus Egyetem pénzügy szakán kezdte adjunktusként, emellett a London Business School és az Erasmus University vendégelőadója is volt. A Budapesti Corvinus Egyetem pénzügy szakán doktorált, ezt megelőzően a Sunderland University Számítógép Szimuláció és Modellezés szakán mesterdiplomát szerzett.

\section{SUMMARY}

Adam Farkas is the first Executive Director of the European Banking Authority, a position he has held since 2011. Previously, he was the Chairman of the Hungarian Financial Supervisory Authority in 2009-2010. Prior to joining the regulatory and supervisory community, he held senior positions in the banking sector including three years as the Co-CEO of CIB Bank, Intesa Group's subsidiary in Budapest, and another three years at the helm of Allianz Bank, setting up a retail banking operation for the market leading insurance company in Hungary. Before that he spent four years as a central banker as a Managing Director and Member of the Board of the National Bank of Hungary with responsibility for reserve management and market operations. He started his career as an assistant professor in Finance at Corvinus University, Budapest and was a visiting fellow at London Business School and also at Erasmus University. He holds a doctorate in Finance from Corvinus University, and an M.Sc. in Computer Based Simulation and Modelling from Sunderland University (UK).
Kulcsszavak: európai pénzügyi intézmények

Key words: European financial institutions

JEL: F33

DOI: $10.18530 / B K .2016 .1 .8$

http://dx.doi.org/1018530/BK.2016.1.8

Közel öt éve tölti be az Európai Bankfelügyeleti Hatóság, az EBA főigazgatói posztját. Véleménye szerint mennyire változtatta meg Európában a felügyeletek szerepkörét a 2007-ben kirobbant válság? Melyek azok a legfontosabb változások, amelyek a válság következtében az európai bankrendszerben, illetve azok szabályozásában történtek?

A globális pénzügyi válság jelentős változásokat hozott az európai pénzügyi szabályozás területén, ezek közül három fontos mozzanatot emelnék ki.

Először is fel kellett ismernünk, hogy az egységes európai piacon, ahol a tőke és a szolgáltatások szabad áramlása már hosszú évek óta szavatolt, a bankok szabadon alapíthatnak leánybankokat, nyithatnak fiókokat más európai uniós országokban, illetve végezhetnek határon átnyúló tevékenységet, a szabályozási és felügyeleti rendszer nem működhet a nemzeti határok által szétszabdaltan. A szabályozásnak és a felügyeleteknek ugyanúgy egységes színtéren, egységes szabályok alapján kell müködniük, mint a felügyelt intézményeknek.

Másodszor: a válság nemcsak Európában, de szélesebb körben is rávilágított a bankrendszerek törékenységére, illetve arra, hogy sokkal szigorúbb és szélesebb körű prudenciális szabályokra, követelményekre van szükség.

Végül: a válság és az azt követő időszak nyilvánvalóvá tette, hogy a felügyeleti eszköztár összeállításának alapelvein is módosítani szükséges. A hatékonyabb felügyelés érdekében szélesebb eszköztárra van szükség, növelni kell a felügyelés intenzitását mind a kockázatelemzési, mind a helyszíni ellenőrzés területén, és ehhez meg kell erősíteni a felügyeleteket.

A tapasztalt változások mennyiben írhatók a pénzügyi válságot követő „első ijedtség” számlájára, vagy amúgy is bekövetkeztek volna?

Ez jó kérdés, amin azóta is sokan és sokat vitatkoznak. Valószínűleg mindkét tényezőnek szerepe lehetett. A pénzügyi instrumentumok, illetve pénzügyi rendszer normális fejlődése, egyre szofisztikáltabbá válása folyamatosan újabb és újabb kockázatokat eredményez, amelyek egy szerves fejlődés keretében is újabb és újabb feladatokat adnak a szabályozónak és az intézményeket felügyelő szervezeteknek is.

Másfelől viszont az is igaz, hogy a nagy pénzügyi válságok minden esetben felszínre hozzák a rendszer gyengeségeit, ez a válság is óriási egyszeri lökést adott a szabályozási változásoknak, elég, ha a globális Bázel III egyezményre vagy a banki válságkezelési és szanálási szabályok módosításának szükségességére gondolunk. 
Röviden mit jelent a pénzintézetek számára - és számunkra, fogyasztók számára - a Bázel III követelményrendszer bevezetése?

A Bázel III szabályrendszer bevezetése, ami Európában és az egész világon több éve megkezdődött, és még jelenleg is tart, alapvető és átfogó változásokat hoz a bankokkal szembeni prudenciális követelmények rendszerében. Megalkotásának elsődleges célja nem a fogyasztóvédelem volt, hanem a bankok biztonságos müködését szavatoló, prudenciális elöírások módosítása. A bankok biztonságosabb működését többek között új, szigorúbb tőkemegfelelési szabályok, újonnan bevezetett likviditási előírások és a bankok tőkeáttételének korlátozása garantálják. Amit ebből a fogyasztó is érzékelni fog, az az, hogy az egyedi bankok szintjén, illetve a bankrendszer egészének szintjén is biztonságosabb lesz a pénzügyi rendszer működése, csökken a válságok kialakulásának valószínűsége, ezáltal a bankok ügyfeleinek, a betéteseknek a pénze is nagyobb biztonságban lesz.

\section{Mennyiben fog nagyobb biztonságot teremteni az európai bankrendszer számára az} Európai Központi Bank európai nagybankok egységes felïgyeletét célzó csomagja?

Véleményem szerint az új felügyeleti intézményrendszer lényegesen nagyobb hatékonysággal tudja majd ellátni feladatát. A korábbi szisztéma, illetve szabályozás alapján a 28 európai uniós tagállam bankrendszerét 28 nemzeti felügyelet ellenőrizte viszonylag gyenge koordináció mellett. Bebizonyosodott, hogy azok a nagyobb bankok, bankcsoportok, amelyek több országban is jelen vannak, illetve határon átnyúló szolgáltatásokat nyúitanak, jelentős, rendszerszintű kockázatokat rejthetnek magukban. Ahogy korábban is említettem, ez felvetette az egységes európai szabályozás igényét és szükségességét. Az eurózónán belül, tekintettel a valutaunió pénzügyi rendszerének mélyebb integrációjára, ezen túlmenően egységes bankfelügyeletre van szükség, mert enélkül továbbra is fennállna a zóna pénzügyi rendszere széttöredezésének veszélye. Az Európai Központi Bank, az eurózóna egységes bankfelügyeleti szerepkörében (SSM) eljárva kidolgozott egy módszertant, amelynek alapján meghatározható, hogy mely bankok sorolhatók a kockázati szempontból „jelentős", és melyek a kockázatosságukat tekintve „kevésbé jelentős” pénzintézetek körébe. A besorolás figyelembe veszi az egyes bankok méretét, az egyes tagállamok bankrendszerének lefedettségét és egyéb szempontokat is. A rendszerszinten „kevésbé jelentős” kockázatú kategóriába sorolt pénzintézetek felügyeletét továbbra is a nemzeti felügyeletek látják el, de az SSM integrált módszertani útmutatása szerint a teljes európai bankrendszerre, annak biztonságára nagyobb hatással bíró pénzintézeteket, összesen mintegy 130 intézményt közvetlenül az egységes felügyelet, az SSM ellenőrzi a nemzeti hatóságok bevonásával.

Számos elemző állítja, hogy a bankrendszerek világszinten „bizalomdeficittől” szenvednek, és a legkisebb bizonytalansági tényező is azonnali, erőteljes reakciókat vált ki. Vajon a tervezett magasabb szintü felügyelés növelheti a nemzeti/nemzetközi

\section{bankrendszerekbe vetett bizalmat?}

A válság kitörését követő években egyértelműen megmutatkozott egyfajta „bizalomdeficit”, emellett a világ legtöbb országában megjelentek és felerősödtek a kimondottan bankellenes hangok is.

Én arra számítok, hogy azoknak a jelentős erőfeszítéseknek, amelyek a rendszer megerősítését és a bizalom visszaállítását célozzák, meglesz az eredménye.

Az Egyesült Államok és az Európai Unió pénzintézeteinek tőkehelyzetét tekintve jelentős előrelépés történt, aminek eredményeképpen stabilizálódott a pénzügyi intézmények tőkepiaci megítélése. Ezt az is mutatja, hogy az elmúlt hetekben-hónapokban nemegyszer jelentős volatilitást tapasztalhattunk a banki papírok piacán, ugyanakkor ennek nem voltak a rendszer szintjén megmutatkozó, bizalomvesztést okozó következményei. A bankrendszerek válságtűrő képessége megerősödött, stabilitása nőtt.

Másfelöl viszont az is igaz, hogy ez elsősorban a befektetői körről mondható el, a széles értelemben vett társadalom, a lakosság számára a bizalmi tőke visszaszerzése lassabb folyamat, több időt igényel.

2014-ben lezajlott az európai bankok stressztesztje, és a vizsgálatot 2016-ban is megismétlik. Hatékony eszköz lehet ez a módszer a hatóság kezében?

A stresszteszt azon - hosszabb ideje ismert és alkalmazott - felügyeleti eszközök egyike, amelyek szerepe a válság kirobbanása után, illetve azt követően jelentősen megváltozott. A stressztesztek során a bankok mérlegét a hatóságok olyan hipotetikus kockázatok hatásának teszik ki, amelyeknek előfordulási valószínűsége ugyan kicsi, de kedvezőtlen esetben mégis realizálódhatnak. Ezek a vizsgálatok megmutatták, hogy a pénzintézetek tőkeellátottsága elégséges lenne-e arra, hogy ilyen extrém körülmények között, azaz jelentős stressz esetén is megőrizzék működőképességüket.

A válság kirobbanása idején a stressztesztek célja elsősorban az volt, hogy viszonylag rövid időn belül jelentős tőkeemelésekhez vezessenek azoknál a bankoknál, ahol erre a teszt alapján szükség volt.

Miután az európai bankrendszerben összességében megtörtént a bankok számottevő és átfogó feltőkésítése, ennek a felügyeleti eszköznek a szerepe is átértékelődött, és fokozatosan belesimul a mindenkori „normális” felügyeleti kockázatértékelési munkába. Stressztesztekkel ma elsősorban azt vizsgáljuk, hogy az egyes bankok milyen speciális, az üzleti modelljükből fakadó kockázatoknak vannak kitéve. Például teszteljük egyes pénzintézetek devizakitettségét ott, ahol ez a típusú kockázat kiemelkedő, egy fetételezett devizapiaci stressz segítségével. Vagy például a jelzálog-hitelezés területén különösen aktív bankok számára egy ingatlanpiaci válság jelenthet komoly kockázatot, esetükben ilyen feltételezett hatásokat veszünk górcső alá. A stresszteszt mint vizsgálati módszer, vizsgálati lehetőség így inkább az egyedi, az egyes bankokra jellemző kockázatok azonosításának irányába mozdul el, ahol az egyes kockázatok miatt szükséges addicionális tőkekövetelmények megállapításához használják a felügyeletek. 
Végezetuil engedjen meg egy, a bankrendszer mellett más pénzügyi intézményrendszereket is érintő kérdést. Az utóbbi időben többször felmerült az európai betétbiztosítási rendszerek egységesítésének szükségessége. Az egységes bankpiac, illetve a határon átnyúló szolgáltatások szintén felvetik ezt a kérdést. Sőt, a csődbe ment Astra biztosító magyarországi fióktelepével kapcsolatos anomáliák szintén ráirányították a figyelmet arra, hogy - igaz, más pénzügyi területen, de - lehetnek „lyukak” a felügyeleti rendszerekben. Emellett az eltérő garanciaszabályok léte további anomáliák táptalaja lehet. Mi erről a véleménye?

Ez a problémakör ismét visszavezet ahhoz a válság okozta felismeréshez, amely szerint az egységes európai piacon, akár fióktelepi, akár határon átnyúló intézmények működéséről beszélünk, nemigen létezhet biztonságos működés anélkül, hogy a szabályozás - így például a betétesek vagy a biztosítot tak védelme - azonos ne legyen. Ha a szabályok nem egységesek, és a garanciális rendszerek nem nyújtanak ugyanolyan védettséget az egyik országban, mint a másikban, akkor olyan helyzetet hozunk létre, hogy az egyik tagországban betétként elhelyezett egy euró más értékü, mintha ugyanazt az egy eurót a bankcsoport egy másik tagországbeli bankfiókjában helyeztük volna el. Hasonló a helyzet a biztosítottak védelmét ellátó garanciarendszer kérdésében is.

A bankszektor tekintetében jelenleg is zajlik a vita az Európai Bizottság javaslatáról, amelynek éppen az lenne a célja, hogy az előbbi elfogadhatatlan helyzetet az eurózónán belül megszüntesse. A betétesek biztonságát szavatoló európai garanciarendszer bevezetése a javaslat szerint több lépcsőben, fokozatosan történne, és - önkéntesen - más, nem eurózónához tartozó tagországok is csatlakozhatnának hozzá.

Meg kell azonban említeni, hogy az ilyen típusú egységes garanciarendszerre irányuló szabályozási javaslatok a bankrendszerre vonatkozóan elörébb járnak, a biztosítási szektorra nézve ezek a konkrét javaslatok még váratnak magukra. 